\title{
Loanwords in the Urban Meccan Hijazi Dialect: An Analysis of Lexical Variation according to Speakers' Sex, Age and Education
}

\author{
Sameeha D. Alahmadi ${ }^{1}$ \\ ${ }^{1}$ MA in linguistics, Newcastle University, UK \\ Correspondence: Sameeha Alahmadi, 2 Epsom Court, Kingston Park, NE3 2UP, Newcastle upon Tyne, UK. \\ E-mail: sameehaalahmadi@gmail.com
}

Received: November 16, 2015 Accepted: November 26, $2015 \quad$ Online Published: November 30, 2015

doi:10.5539/ijel.v5n6p34 URL: http://dx.doi.org/10.5539/ijel.v5n6p34

\begin{abstract}
This study aims to investigate the degree of lexical variation in Urban Meccan Hijazi Arabic (UMH) by identifying the loan words that are commonly spoken in this dialect and determining from which languages they have been borrowed. Also, it explores the effect of social factors such as age, sex and educational level on the use of loan words by UMH speakers. For the purpose of the study, I designed a questionnaire and distributed it to eighty participants whose mother tongue is UMH. The sample consisted of three groups, namely, old and young, male and female and educated and uneducated participants. In order to provide answers to the research questions, the questionnaire was divided into two sections; section one investigates the participants' background, i.e., their age, sex, educational level, how long have they been living in Mecca, etc., and section two examines their use of the loan words in UMH. The results revealed that in addition to some words that have been borrowed from Persian and Italian, most of the loan words found in UMH have been borrowed from Turkish. This could have resulted from the Ottoman occupation of Saudi Arabia for around 400 years, and the interaction with pilgrims who visit Mecca every year. Additionally, the results of the t-tests showed that the differences between the three groups (i.e., old vs. young, male vs. female and educated vs. uneducated) are statistically significant. This indicates that the three social factors play a crucial role in the participants' use of the loan words in UMH. Finally, the study concludes with some recommendations for further research.
\end{abstract}

Keywords: borrowing, lexical variation, age, educational level, sex, loan words, Meccan Hijazi Arabic

\section{Introduction}

This study has been conducted to investigate lexical variation in Urban Meccan Hijazi dialect (henceforth, $\mathrm{UMH}$ ), which is a dialect of Arabic spoken in Mecca. Particularly, it gives special attention to the historical influence on its lexical features, and how factors such as sex, age, and educational level may have played a role in the lexical variation between the speakers of UMH. Prior to embarking on this study, I have devoted a significant amount of time and effort to research the lexical variations associated with the dialect and the factors that triggered these variations. It has been observed that UMH has borrowed many words from other languages such as Turkish, Persian, Urdu, Malay, French and Italian. This is due to the fact that Muslims from all over the world need to visit Mecca, at least, once in their life time in order to fulfil one of the pillars of Islam, namely, pilgrimage. This influx of visitors to Mecca may have resulted in borrowing different words from different languages. In addition, to the best of my knowledge, no study has been conducted to study such variation. Therefore, this study pays special attention to one linguistic variation, i.e., lexical variation in UMH. The next section reviews some of the most prominent studies related to linguistic variation and change, showing the reasons beyond these variations based on social factors such as age, sex and educational level.

\section{Literature Review and Background of the Study}

\subsection{Overview}

It has been observed that change in lexical items is one of the most frequent types of linguistic change that can be easily identified. This change can be divided into three main categories: creation of new lexical items, change of meaning and loss of lexical items (McMahon, 1994). It has also been noted that variation in lexical items is highly observable when comparing various regions. For example, Carver (1987, p. 268) noted that 'a carbonated soft drink' could be referred to as 'pop' in the inland North and West in the USA, whereas it is called 'tonic' in 
Eastern New England, 'Soda' in the Northeast, and 'drink', 'cold drink' or 'dope' in different parts in the South. Hence, one of the reasons behind lexical variation could be geographical.

Sometimes the difference, whether lexical or phonological, in a certain dialect could be a result of the influence of foreign languages that have significantly affected the local language spoken in that area (Ibn Khaldūn \& Rosenthal, 1967). Particularity, Ibn Khaldūn and Rosenthal (1967) justified the lexical changes in the dialects of Arabic spoken by Arabs in the East as a direct outcome of contact with Persian and Turkish in the East. This contact has resulted in borrowing a number of words from these languages. Such borrowings could have taken place due to many reasons. For instance, Ahangari and Moradi (2013) included many examples of Arabic vocabularies that have been borrowed from Persian due to the commercial and economic contact between Iranians and Arabs, since the time of the Achaemenid Empire. Another reason is that some Arabs migrated to Iran because of drought and started to propagate the Iranian language and culture in the country upon their return. Thus, the extensive interaction and communication with Iranians influenced Arabs and caused many vocabularies to be integrated into Arabic. Some of the lexes integrated into Arabic directly from Persian retained their Persian form and shape in Arabic.

In many sociolinguistics studies on language variation and change, it can be noted that special attention has been given to phonological changes and how they can be affected by various social variables such as age, sex, education, etc. However, lexical variation has been under studied in both sociolinguistics and corpus linguistics (Grondelaers \& Geeraerts, 2003). Specifically, studies focusing on the actual choices selected for a certain name as a designation of a certain referent are quite rare (Grondelaers \& Geeraerts, 2003). Therefore, one may argue that more studies are needed on lexical variation and change in various languages and dialects to shed light on: (1) how they take place; and (2) the social factors that may play a role in such variation.

Since the three main social variables, i.e., sex, age and educational level are the independent variables in the current study, the work done on these variables have been prioritised in this section. Specifically, it provides a description of a number of studies in which sex, age or educational level have had an impact on variation.

2.2 Age

Investigating the realisations of the two diphthongs [ay] and [aw] e.g., 'house' and 'mice', Labov conducted a study in Martha's Vineyard Island in 1961. Specifically, he conducted interviews with a number of participants who belonged to different ethnic groups and ages. Labov observed that within the young speakers group (31-45 years old), the individuals were moving away from any pronunciations related to the standard New England norms. In contrast, they were moving towards a pronunciation usually associated with Vineyard speakers, especially the conservative Chilmark fishermen (Labov, 1972, p. 101). Young speakers were the prominent users of this type of pronunciation. They intended to identify themselves as the true Vineyarders by rejecting the values associated with the mainland, and resenting the intrusion of the rich summer visitors on the traditional life style on the island. Therefore, Labov noted that the young speakers sought to use the non-standard variety to a great extent. He (1972, p. 39) also noticed that this trend appeared in spite of the exposure to the educational system; the most prominent users of the vernacular vowels were college educated boys on the island. Particularly, a small number of fishermen started to exaggerate a tendency which was already there in their speech. This tendency seems to have emerged subconsciously so that they can be recognised as a superior separate social group to the unwanted summer visitors. In fact, a group of islanders considered this group of young men as the revivers of old good values; hence, they started to imitate the way this group talks subconsciously. These islanders considered the way young men pronounced vernacular vowels an innovation. Therefore, as time passed by, the new pronunciation became the normal way of speaking for the people who lived in Martha's Vineyard.

In sum, based on Labov's study, one may observe that the idea that changes will mostly be noticeable in the speech of young people and less noticeable in the speech of old speakers may not always hold true. In contrast, the old speakers have triggered the change in order to demonstrate solidarity on the one hand, and to show that the tourists are intruders and the locals are the true islanders on the other. Most importantly, Labov's study indicated that change may not be only triggered by the desire to speak like other people since they may be prestigious; the individual may spend a great amount of time with them or these people could be powerful.

\section{$2.3 \mathrm{Sex}$}

One of the most essential studies which examined how sex and the way speakers of a certain speech community are linked to each other within social networks that may be open or close is Milroy's (1987) Belfast. She investigated the correlation between how individuals are integrated in a certain community and how those individuals speak. Milroy measured the use of many linguistic variables, which included sounds that represent both standard and non-standard forms e.g., /a/ in 'fat' and / $/$ / in 'father'. The results revealed that there was a 
correlation between the use of non-standard forms and a high Network Strength Score. This usually meant that men whose speech was characterised by a high usage of non-standard forms had been found to be members of tight-knit social networks. Contrarily, non-standard forms were less salient in women's speech, since women tend to be members of less dense networks. Nevertheless, concerning other variables, the pattern in which women use standard forms, whilst men use non-standard forms was reversed. For instance, in the Hammer and Clonard, contrary to what is expected, a big number of women had a tendency to use a non-standard or vernacular form of /a/ as in 'fat'. According to Milroy, this tendency could be accounted for by relying on the social pressures found in the communities. Both the Hammer and the Clonard exhibited unemployment rates of approximately $35 \%$. This had a big impact on social relationships. It has been observed that men from such areas had to look for jobs outside the community. On the other hand, the women went out to work in those areas, and with regard to the young Clonard women, all of them worked together. Working together meant that they are members of a dense network; hence, their lives were very much interconnected.

Finally, a study has been conducted by Altakhaineh and Rahrouh $(2015$, p. 4), who attempt to measure the awareness of Arab EFL learners of euphemistic expressions related to two areas, i.e., courtesy and physical appearance. The study also investigates whether the participants' sex and English proficiency level have an impact on their use of euphemistic expressions while speaking English in their daily speech. The results of the study shows that Arab EFL learners have little awareness of the use of euphemistic expressions in English. In addition, the participants' English proficiency level has a little impact on the leaners' use of euphemistic expressions. On the other hand, the participants' sex plays a crucial role with regard to the use of euphemistic words. That is, the female participants are significantly more aware of the use euphemistic expressions than the male ones (Altakhaineh \& Rahrouh, ibid).

\subsection{Educational Level}

Phonological and lexical variations among the Kashmiri speakers were investigated by Koka (2014, p. 1071) in terms of particular social variables, namely, education, religion, age, region/socioeconomic status and occupation. The results revealed that the participants who were classified as literate pronounce many words quite differently from those classified as illiterate. The former group have been noticed to exhibit a high degree of affinity towards standard Kashmiri. It has been argued by Koka that this affinity towards the standard variety can be attributed to the fact that a large number of the literate speakers are office goers. Thus, they are more likely to stay in contact with the speakers of standard Kashmiri. Conversely, Koka (2014, p. 1076) observed that the illiterate group use the non-standard variety of Kashmiri in their daily conversation. Additionally, it has been noted that the speech of the literate and illiterate groups exhibit remarkable variations in terms of the lexical items they use (Koka, 2014, p. 1081). Similar to the age group A1 whose ages ranged between 15-50 years, the speech of the literate group is characterised by scientific, modern and technical terminologies as opposed to that of the illiterate group. Specifically, the literate group seems to demonstrate a tendency to remain up to date with the latest advances pertinent to modern inventions. Therefore, the fact that they borrow a substantial number of lexical items from other languages such as English seems to be justifiable. Borrowing words from various languages especially English may give them the ability to enrich their repertoire by including modern lexical items. For instance, the literate group say /kUrtanY/ 'shirt, whilst the illiterate group say /kəmi:z/ 'shirt'. Another example is /kamri/ 'room' as produced by the literate group, whereas the illiterate group say /kUțh/ 'room'.

In another recent study on social variables such as educational level and age, Alotaibi $(2015$, p. 69) investigated the extent to which Kuwaiti native speakers of Arabic are aware of euphemism. In particular, he examined the impact of education and age on their comprehension and use of euphemistic expressions in day-to-day conversations. The results revealed that the participants who were educated, holders of university degrees, seem to avoid using insulting words and consider them inappropriate. Also, in terms of rating the appropriateness of taboo words, the participants who were classified as old (50-65 years old) performed better than those who were classified as young (25-40 years old), indicating that taboo words are not suitable and should not be utilised.

Investigating sociolinguistic variation and change based on the interaction with social factors, i.e., age, sex, etc. has received little attention in Arabic dialects, in general, and in UMH in particular. Indeed, a few research studies have been conducted on UMH (e.g., Hurgronje, 1886; Ingham, 1971; Nakshabandi, 1992; Sulieman, 2003; among others). Thus, this study aims to bridge this gap. Particularity, it aims to analyse the differences among speakers of UMH in order to examine the means by which foreign historical influence has affected the lexicon of UMH in relation to age, sex and educational level. Specifically, this study seeks answers to the following research questions: 
1) What are the loan words that are commonly spoken in UMH? and from which languages are they borrowed?

2) Do social factors such as age, sex and educational level affect the use of loan words by UMH speakers? If yes, how and why?

My initial hypothesis is that there are statistically significant differences between old and young, male and female and educated and uneducated speakers of UMH in terms of use of loan words.

\section{Methodology}

\subsection{Research Sample}

The linguistic variable which this study focuses on is the use of loan words in UMH. Such variable can be influenced by social factors such as age, sex and educational level. As a minimum requirement, Tagliamonte (2006, p. 23) argues that a sample of participants in research studies needs to be representative based on sex, age, educational level and/or social class, since these social variables have proved their significance in research on urban speech communities over and over again. Therefore, the selection of the participants in this study took into consideration these social variables in order to detect the degree of lexical variation in UMH and the amount of foreign influence it has undergone.

The current research involved a sample of Urban Meccan Hijazi Arabic residing in Mecca, Saudi Arabia. There were in total 80 participants whose ages ranged between 20 and 70+ years old, and who were born in Mecca and have not lived elsewhere for more than 3 months. The purpose of this restriction was to ensure that the participants were native speakers of UMH, who had not been influenced by other dialects in Saudi Arabia. Since age, sex and educational level are independent variables in the current study, the 80 participants were divided into different groups in terms of these variables. Tables 1-3 below show the distribution of the participants:

Table 1. Distribution of the participants in terms of age

\begin{tabular}{ll}
\hline Number of participants (eighty) & Age \\
\hline 35 & Young (20-45) \\
45 & Old (46-70+) \\
\hline
\end{tabular}

Table 2. Distribution of the participants in terms of sex

\begin{tabular}{ll}
\hline Number of participants (eighty) & Sex \\
\hline 40 & Male \\
40 & Female \\
\hline
\end{tabular}

Table 3. Distribution of the participants in terms of educational level

\begin{tabular}{ll}
\hline Number of participants (eighty) & Educational level \\
\hline 30 & Uneducated \\
50 & Educated \\
\hline
\end{tabular}

The participants were selected based on a simple random sampling technique, in which every person in the population of the study (i.e., the residents in Mecca who are easily accessed) has an equal chance of being selected (Meyerhoff et al., 2015). The reason for doing this was to reduce human bias and try to ensure that the chosen sample as representative of the population as possible. Although a complete list of the individuals within the population may never be attained, this technique may help in making generalisations from the sample to the whole population (Meyerhoff et al., 2015). The following two sections outline the research instrument and data collection method.

\subsection{Research Instrument}

For the purpose of the study, a questionnaire containing 43 items was given to 80 participants to complete (see Appendix A). Not only do questionnaires allow the researcher to investigate the manner by which individuals behave in certain situations and the type of language they use, but they also exhibit their attitudes and social characteristics (Meyerhoff et al., 2015, p. 71). They also have the advantage of collecting a considerable amount of data in a short time. Such research instrument has been used for decades to obtain data pertinent to dialectology (see Chambers \& Heisler, 1999). This investigation has resulted in the Dictionary of American Regional English (DARE) (Note 1). In this questionnaire, the structure of the questions took different forms. Put 
plainly, the informants were asked, for instance, to: fill in the blank in a simple sentence with the appropriate word, write the word in the picture, or a simple 'what do you call this?' question. The questions used in the questionnaire I designed for this study have similar structure to the ones used in the DARE questionnaire. Specifically, the questionnaire was divided into two sections: section one was mostly a multiple-choice test and was dedicated to attaining background information about the participants, i.e., their sex, age, educational level, how long have they lived in Mecca, etc. Section two tested the participants' use of the loan words found in UMH. In this section, they were not provided with any choices because I aimed to test their ability to produce the words without any interference or influence. Additionally, the questions in this section were written in UMH, which was used as an incentive for them to answer in UMH not in Modern Standard Arabic (MSA) (Note 2).

Prior to distributing the final version of the questionnaire, it should be noted that a pilot study was conducted to develop and test the adequacy of the research instrument. Therefore, an earlier version of the questionnaire was given to 10 volunteers as a pilot study to check whether the questions are vague or easily understood (cf. Johnson, 1996, pp. 7-8). The pilot work facilitated the design of the final questionnaire and gave an idea about how the participants might be expected to respond.

In conducting the study, I also took steps to reduce the effects of the observer's paradox (Labov, 1972, p. 209) who stated that "the aim of linguistic research in the community must be to find out how people talk when they are not being systematically observed; yet we can only obtain these data by systematic observation". Therefore, I made sure that I did not stay close to the participants while they were answering the questionnaire to minimise any inconvenience. Additionally, I attempted to avoid asking them direct questions, so that I did not direct their attention to the words they used or had they spoken. Also, two distracters were included in the questionnaire to avoid giving them an idea about the exact objective of the questionnaire.

\subsection{Data Collection}

I randomly distributed the questionnaire to people in the streets of Mecca in order to record their responses on the targeted items, taking into consideration that the participants had to be born in Mecca and had been living there his/her whole life. This was important, since I needed native speakers of UMH to fill in the questionnaire (see Appendix A). It should be noted that I took into consideration the ethical issues pertinent to dealing with human participants. For instance, I ensured the participants of the confidentiality of the information they provide. I also informed them that their participation in this study is completely voluntary and thanked them for their cooperation.

\subsection{Statistical Analysis}

For the quantitative analysis, I utilised the latest version of the Statistical Package for Social Sciences (SPSS). Means and standard deviations of the participants' answers were calculated to provide a clear picture of the differences between the answers of the three groups based on the social variables, i.e., age, sex and educational level. Calculating means and standard deviations facilitated the comparison between the answers of different groups. Additionally, in order to check whether the social variables had any impact on the participants' answers, t-tests were utilised. By comparing the means of the groups, I can check whether the differences between the participants' answers were statistically significant (i.e., obtain the $p$ value). This means that a clear idea about whether sex had any effect on the participants' use of UMH can be revealed through the t-test. The next section reports on the results and discusses them.

\section{Results and Discussion}

The results in this section are presented in accordance with the sections found in the questionnaire (see section 2.2). Through this section, I was able to check whether the social factors (i.e., age, sex and educational level) had any influence on the participants' answers on the test.

\subsection{Loan Words in UMH}

Regarding first research question, the results showed that UMH has borrowed words from various languages such as Turkish, Persian and Italian. In particular, the results of the etymology revealed that most loan words used by UMH speakers can be traced back to Turkish (Suleiman, 1994). This could be due to the fact that Saudi Arabia was under the control of Ottomans for approximately four centuries. During this time, some words have been borrowed from Turkish into Arabic (Suleiman, 1994). In certain instances, the loan word has been borrowed from Turkish in its original form and pronunciation. For instance, the Turkish word tandah 'the roof window of the car' has been borrowed into UMH as it is originally in Turkish. In contrast, other words have been borrowed and integrated into UMH with some phonological adaptation and without any change in meaning. For example, the Turkish word Köprü 'bridge' has been borrowed and integrated into UMH as [kobri:] 'bridge' 
(Suleiman, 1994).

Other words from Persian and Italian have also been found in UMH. For example, the word Villa has been borrowed from Italian and integrated into UMH. These words could have found their way into UMH as a result of pilgrimage. Every year, millions of Muslims from different countries around the world visit Mecca to fulfil one of the pillars of Islam, i.e., pilgrimage. The people of Mecca communicate with the pilgrims at the mosques, market and other public places such as restaurants. Therefore, some words from different languages could have been borrowed by the people of Mecca through time (PC. Aldakeer, 2015). Table 4 below shows the loan words I found in UMH by contacting (PC. Aldakeer, 2015). The origin of these loan words was checked twice; firstly, by asking native speakers of the languages from which the words were borrowed; and secondly through checking the etymology of these words (PC. Aldakeer, 2015).

Table 4. Origin of loan words found in UMH

\begin{tabular}{|c|c|c|c|c|c|c|c|}
\hline Loan word & Word in UMH & Origin & Translation & $\begin{array}{l}\text { Loan } \\
\text { word } \\
\end{array}$ & Word in UMH & Origin & Translation \\
\hline Boş & $\begin{array}{l}{[\text { bo::] bosh }} \\
\text { (Note 3) }\end{array}$ & Turkish & Empty & Köprü & $\begin{array}{l}{[\text { kobri:] }} \\
\text { kobrii }\end{array}$ & Turkish & Bridge \\
\hline Belki & $\begin{array}{l}\text { [balkin] } \\
\text { balkin }\end{array}$ & Turkish & Maybe & Terlik & $\begin{array}{l}\text { [tilik] } \\
\text { tilik }\end{array}$ & Turkish & Slippers \\
\hline çekiç & $\begin{array}{l}\text { [fa:ku:f] } \\
\text { shaakoosh }\end{array}$ & Turkish & Hammer & Kese & $\begin{array}{l}{[\mathrm{ki}: \mathrm{s}]} \\
\text { kiis }\end{array}$ & Turkish & Sack \\
\hline kürek & $\begin{array}{l}\text { [ko:re:k] } \\
\text { kooreek }\end{array}$ & Turkish & Shovel & Sutyen & $\begin{array}{l}\text { [sutya:nih] } \\
\text { sutyaanih }\end{array}$ & Turkish & $\mathrm{Bra}$ \\
\hline Doğru & $\begin{array}{l}\text { [doyri:] } \\
\text { doghrii }\end{array}$ & Turkish & Straight & Sokak & $\begin{array}{l}\text { [zuqa:q] } \\
\text { zughaagh }\end{array}$ & Turkish & Ally \\
\hline Aferin & $\begin{array}{l}\text { [Yafa:rim] } \\
\text { 'afaarim }\end{array}$ & Turkish & Well done & Çanta & $\begin{array}{l}{\left[\int_{\text {ant }}{ }^{\prime} \mathrm{a}\right]} \\
\text { shanța }\end{array}$ & Turkish & Bag \\
\hline Bahşiş & $\begin{array}{l}\text { [baxfi:[] } \\
\text { bakhshiish }\end{array}$ & Turkish & Tip & Masa & $\begin{array}{l}{\left[\mathrm{ma}: \mathrm{s}^{\mathrm{s}} \mathrm{a}\right]} \\
\text { maașa }\end{array}$ & Turkish & Table \\
\hline Çizme & $\begin{array}{l}\text { [dzazmih] } \\
\text { jazmih }\end{array}$ & Turkish & Boot & Terzi & $\begin{array}{l}\text { [tarzi] } \\
\text { turzi }\end{array}$ & Turkish & Tailor \\
\hline Pembe & $\begin{array}{c}\text { [bamba] } \\
\text { bamba }\end{array}$ & Turkish & Pink & Sifir & $\begin{array}{l}{\left[\mathrm{s}^{\mathrm{s} i f i r}\right]} \\
\text { sifir }\end{array}$ & Turkish & Zero \\
\hline Taza & $\begin{array}{l}{\left[\mathrm{t}^{\mathrm{G}} \mathrm{a} z \mathrm{za}\right]} \\
\text { țaaza }\end{array}$ & Turkish & Fresh & Tercüman & $\begin{array}{l}\text { [turdzma:n] } \\
\text { turjmaan }\end{array}$ & Turkish & Interpreter \\
\hline Bataneha & $\begin{array}{l}\text { [bat a:niyye] } \\
\text { bațaaniyyeh }\end{array}$ & Turkish & Blanket & Tandah & $\begin{array}{l}\text { [tandah] } \\
\text { tandah }\end{array}$ & Turkish & $\begin{array}{l}\text { The roof window } \\
\text { of the car }\end{array}$ \\
\hline Derikseon & $\begin{array}{l}\text { [dirkisyo:n] } \\
\text { dirkisyoon }\end{array}$ & Turkish & Car wheel & Tashat & $\begin{array}{l}{\left[\mathrm{t}^{\mathrm{s}} \mathrm{oft}\right]} \\
\text { tosht }\end{array}$ & Persian & Bucket \\
\hline Pantalon & $\begin{array}{l}\text { [bant'alo:n] } \\
\text { banțaloon }\end{array}$ & Turkish & Trouser & Villa & $\begin{array}{l}\text { [vi:1la] } \\
\text { veella }\end{array}$ & Italian & Villa \\
\hline Istasyon & $\begin{array}{l}\text { [?istisyo:n] } \\
\text { 'stisyoon }\end{array}$ & Turkish & Station & Bahçe & $\begin{array}{l}\text { [baxfa] } \\
\text { bakhsha }\end{array}$ & Turkish & Garden \\
\hline Boya & $\begin{array}{l}\text { [bo:ya] } \\
\text { booya }\end{array}$ & Turkish & Paint & Kapot & $\begin{array}{l}\text { [kabbu:t] } \\
\text { kabbuut }\end{array}$ & Turkish & $\begin{array}{l}\text { The front cover of } \\
\text { the car }\end{array}$ \\
\hline
\end{tabular}

Table 4 shows the loan words used by UMH speakers in this study. As mentioned previously, prior to embarking on this study, I have devoted a significant amount of time and effort to research the loan words used in UMH. Table 4 shows several words I was able to find. Then, I designed the questionnaire to test UMH speakers' use of these words. I only used the loan words (see Table 4) that are mostly used in daily conversations, rather than the ones used in specific domains. The following subsection provides the participants' results on the second section of the questionnaire which deals with their use of the loan words used in UMH.

\subsection{The Participants' Use of Loan Words in UMH}

\subsubsection{Age}

Moving on to the second research question, I start with age. Table 5 shows the results of the t-test of the first group in the sample. 
Table 5. Results of the t-test of the age groups (old vs. young)

\begin{tabular}{lllllll}
\hline Age & Number of participants & Mean & $\begin{array}{l}\text { Standard } \\
\text { deviation }\end{array}$ & T score & Degree of freedom & P value \\
\hline Younger $(20-45)$ & 35 & 6.0 & 3.5 & 1.9 & 78 & 0.03 \\
Older $(46-70+)$ & 45 & 7.4 & 6.4 & & & \\
\hline$* * P<0.05$. & & & &
\end{tabular}

** $\mathrm{P}<0.05$.

An examination of Table 5 shows that the older participants $(\mathrm{m}=7.4)$ used the loan words more than the younger speakers $(\mathrm{m}=6.0)$. The $p$ value $(0.03)$ is lower than $(0.05)$, which means that the difference between the two age groups included in this study was statistically significant. Thus, it can be argued that age as a social factor plays a role in the participants' use of loan words in UMH. Table 6 summarises the participants' answers on each item in the second section of the questionnaire; it shows the proportion of positive responses in each age group.

Table 6. The proportion of positive responses in each age group

\begin{tabular}{|c|c|c|c|}
\hline No. & Loan word & Younger (20-45) & Older $(46-70+)$ \\
\hline 1. & [balkin] & $60 \%$ & $69 \%$ \\
\hline 2. & [bamba] & $63 \%$ & $67 \%$ \\
\hline 3. & [Yafa:rim] & $54 \%$ & $78 \%$ \\
\hline 4. & [sutya:nih] & $51 \%$ & $64 \%$ \\
\hline 5. & [bax $\left.\int a\right]$ & $57 \%$ & $73 \%$ \\
\hline 6. & [boya] & $46 \%$ & $40 \%$ \\
\hline 7. & [kabbu:t] & $66 \%$ & $67 \%$ \\
\hline 8. & [kobri:] & $71 \%$ & $62 \%$ \\
\hline 9. & [bant'alo:n] & $57 \%$ & $60 \%$ \\
\hline 10. & [bax $\left.\int \mathrm{i}: \int\right]$ & $49 \%$ & $56 \%$ \\
\hline 11. & [tarzi] & $40 \%$ & $78 \%$ \\
\hline 12. & {$\left[\mathrm{ma}: \mathrm{s}^{\mathrm{s}} \mathrm{a}\right]$} & $71 \%$ & $80 \%$ \\
\hline 13. & {$\left[\mathrm{~s}^{\mathrm{s}}\right.$ ifir $]$} & $63 \%$ & $84 \%$ \\
\hline 14. & [dzazmih] & $66 \%$ & $42 \%$ \\
\hline 15. & {$\left[t^{f} a: z a\right]$} & $60 \%$ & $78 \%$ \\
\hline 16. & [?istisyo:n] & $57 \%$ & $71 \%$ \\
\hline 17. & [ko:re:k] & $77 \%$ & $69 \%$ \\
\hline 18. & {$[\mathrm{ki}: \mathrm{s}]$} & $43 \%$ & $87 \%$ \\
\hline 19. & {$\left[\int a n t^{\varsigma} a\right]$} & $54 \%$ & $80 \%$ \\
\hline 20. & [zuqa:q] & $66 \%$ & $82 \%$ \\
\hline 21. & [bat ${ }^{\varsigma}$ a:niyyeh] & $60 \%$ & $71 \%$ \\
\hline 22. & [tandah] & $69 \%$ & $69 \%$ \\
\hline 23. & [doyri:] & $74 \%$ & $67 \%$ \\
\hline 24. & [tilik] & $51 \%$ & $89 \%$ \\
\hline 25. & [bo:f] & $66 \%$ & $98 \%$ \\
\hline 26. & [ aa:ku:]] & $60 \%$ & $84 \%$ \\
\hline 27. & [turdzma:n] & $66 \%$ & $78 \%$ \\
\hline 28. & [dirkisyo:n] & $40 \%$ & $96 \%$ \\
\hline 29. & {$\left[\mathrm{t}^{\mathrm{s}} \mathrm{o} \mathrm{t}\right]$} & $77 \%$ & $100 \%$ \\
\hline 30. & [vi:lla] & $66 \%$ & $89 \%$ \\
\hline \multicolumn{2}{|c|}{ Total mean } & $60 \%$ & $74 \%$ \\
\hline
\end{tabular}

Table 6 shows that the older participants (74\%) used the loan words in UMH more than the young participants (60\%). The highest percentage of answers provided by the younger speakers was $77 \%$, whereas the highest percentage of answers provided by the older speakers was $100 \%$. One reason for this result could be that old people living in Mecca have lived in the period during which Ottomans ruled the Arabian Peninsula, especially at the beginning of the $20^{\text {th }}$ century. Therefore, they have been greatly influenced by the language used at the period. In fact, many older participants knew that these words are loan words, since they used to speak Turkish fluently, and some of them still do. The higher percentage of correct answers provided by older participants could be ascribed to the fact that they were impressed by the new culture and civilisation which were associated with Turkey at that time. The Turkish civilization was linked to Turkey's royalty. As it is well known, many people have a tendency to imitate the speech of the dominant group in the society. When the variety has overt 
prestige, it means that an individual uses a variety which is characterised as being the one used by the culturally dominant group (Labov, 1972, pp. 46-49). Due to the high status of Turkish at the time of the Ottoman Empire, Meccan people aimed to imitate people who belonged to the high class in the community and use the same words they use. With regard to Iranian language influence, Meccan people were influenced by the Persian civilisation because Iranians were among the richest people who came to Mecca constantly as pilgrims or traders. Therefore, Meccan people attempted to keep up with them and to imitate them by learning their language.

The second reason for the older participants' result could be attributed to communicating with foreign pilgrims during the last six to seven decades. Most of Meccan people at that time took part in serving pilgrims from different nationalities, i.e., Turkish, Iranian, Indonesian and Indian nationalities. This may have led them to be exposed to various lexical items used by those pilgrims. Additionally, such contact lasts for four months at least every year when the pilgrim stay in Mecca. This time may have been enough for Meccan people to pick up many words from different languages.

The fact that old people in Mecca know that some of the words in UMH are loan words and they may know the origin of some of these the loan words used in UMH and are still using them. For instance, $80 \%$ of the older participants knew that the word [bax a] 'garden' is borrowed from Turkish. In comparison, many young people do not know that these words are loan words. This could be due to various reasons. Probably, young speakers of UMH believe the loan words are part of their native language because they do not know the origins of the words. That is, they have no reason to think that they are not native words. For instance, many young participants were not aware of the fact that a word such as baxfa 'garden' is not in fact Arabic; they did not know that it is a Turkish word. Possibly, this could be due to the fact that they have not lived in the period in which Turkish was the dominant language. Therefore, they may not be aware of the fact that many words they use in their daily conversations have been borrowed from other languages such as Turkish. A look at Table 6 shows that the younger participants used a small number of the loan words more than the older participants. For example, $71 \%$ of the younger speakers used the loan word [kobri:] 'bridge', whilst $62 \%$ of the older speakers used it. The same applies to the three loan words [dzazmih] 'boot', [ko:re:k] 'shovel' and [doyri:] 'straight'. The younger participants may not have known that the above words are borrowed from Turkish. They may just think that they are synonyms to the UMH words. Therefore, their use of these loan words may not have been conscious.

Additionally, young speakers of UMH are possibly under more pressure from their peers to speak a certain variety; the influence of the overt norms of speaking could be less than the peer pressure (cf. Cheshire \& Milroy, 1993, pp. 20-21). Specifically, they would prefer to speak English, since it is regarded as the modern language among their peers rather than speak UMH. In Mecca, the language regarded as prestigious by younger speakers is English, so to fit in the modern and 'cool' group, one needs to speak English. However, the overt norms in the society dictate that one should speak UMH rather than English. In the case of younger speakers peer pressure is stronger than the overt norms. On the other hand, according to Cheshire and Milroy (1993: 20-21), old people may not be under pressure to conform to the overt norms of the society; they prefer to preserve the variety they grew up with. Specifically, old people in Mecca may not be as tolerant as young speakers of language variation. This intolerance could be attributed to the fact that they want to preserve the regional dialect, especially with all the exposure they are subject to due to pilgrimage. Since the older participants have been using the loan words for a long time, they consider these words to be part of UMH dialect. In their view, these words are proof of the Turkish influence on UMH, and this influence is much more preferred to the influence of other languages such as English. On the other hand, young speakers do not share the same views held by old people. For them, English and other European languages are prestigious and modern (overt prestige). Therefore, they are more likely to use English words as opposed to UMH words. This may indicate that there has been a change in what sorts of features/language influences are considered prestigious in Mecca over time. In the past, it was Turkish. However, in the present, it is English.

4.2.2 Sex

Moving on to the second social factor, Table 7 shows the results of the t-test of the male and female participants.

Table 7. Results of the t-test of the sex groups (male vs. female)

\begin{tabular}{lllllll}
\hline Sex & Number of participants & Mean & Standard deviation & T score & Degree of freedom & P value \\
\hline Male & 40 & 6.9 & 8.1 & 1.7 & 78 & 0.046 \\
Female & 40 & 5.1 & 8.0 & & & \\
\hline$* * \mathrm{P}<0.05$. & & & & & &
\end{tabular}


A look at Table 7 shows that the male participants $(m=6.9)$ used more loan words compared to the female participants $(\mathrm{m}=5.1)$. The $p$ value $(0.046)$ is less than $(0.05)$, which means that the difference between the two groups was statistically significant. Hence, one may propose that sex as a social factor plays a role in the participants' use of loan words in UMH. Table 8 below shows the percentages and means of the participants' correct answers in terms of sex.

Table 8. The proportion of positive responses in each sex group

\begin{tabular}{|c|c|c|c|}
\hline No. & Loan word & Male & Female \\
\hline 1. & [balkin] & $75 \%$ & $53 \%$ \\
\hline 2. & [bamba] & $63 \%$ & $40 \%$ \\
\hline 3. & [Yafa:rim] & $48 \%$ & $80 \%$ \\
\hline 4. & [sutya:nih] & $25 \%$ & $30 \%$ \\
\hline 5. & [baxfa] & $80 \%$ & $68 \%$ \\
\hline 6. & [boya] & $55 \%$ & $58 \%$ \\
\hline 7. & [kabbu:t] & $98 \%$ & $30 \%$ \\
\hline 8. & [kobri:] & $90 \%$ & $38 \%$ \\
\hline 9. & [bant'alo:n] & $73 \%$ & $65 \%$ \\
\hline 10. & [bax/i:f] & $30 \%$ & $45 \%$ \\
\hline 11. & [tarzi] & $78 \%$ & $33 \%$ \\
\hline 12. & [ma:s $\left.\mathrm{s}^{\mathrm{s}} \mathrm{a}\right]$ & $88 \%$ & $75 \%$ \\
\hline 13. & {$\left[\mathrm{~s}^{\mathrm{s}}\right.$ ifir $]$} & $58 \%$ & $78 \%$ \\
\hline 14. & [dzazmih] & $85 \%$ & $53 \%$ \\
\hline 15. & [ta:za] & $93 \%$ & $33 \%$ \\
\hline 16. & [?istisyo:n] & $43 \%$ & $40 \%$ \\
\hline 17. & [ko:re:k] & $75 \%$ & $80 \%$ \\
\hline 18. & [ki:s] & $80 \%$ & $88 \%$ \\
\hline 19. & [ $\left.\int \mathrm{ant}^{\mathrm{s}} \mathrm{a}\right]$ & $85 \%$ & $33 \%$ \\
\hline 20. & [zuqa:q] & $75 \%$ & $25 \%$ \\
\hline 21. & [bat'a:niyyeh] & $70 \%$ & $60 \%$ \\
\hline 22. & [tandah] & $28 \%$ & $63 \%$ \\
\hline 23. & [doyri:] & $80 \%$ & $85 \%$ \\
\hline 24. & [tilik] & $83 \%$ & $25 \%$ \\
\hline 25. & [bo:f] & $45 \%$ & $28 \%$ \\
\hline 26. & [ $\left.\mathrm{a}: \mathrm{ku}: \int\right]$ & $93 \%$ & $38 \%$ \\
\hline 27. & [turdzma:n] & $68 \%$ & $35 \%$ \\
\hline 28. & [dirkisyo:n] & $70 \%$ & $40 \%$ \\
\hline 29. & {$\left[\mathrm{t}^{\mathrm{s}} \mathrm{oft}\right]$} & $48 \%$ & $43 \%$ \\
\hline 30. & [vi:1la] & $88 \%$ & $78 \%$ \\
\hline \multicolumn{2}{|c|}{ Total mean } & $69 \%$ & $51 \%$ \\
\hline
\end{tabular}

Table 8 demonstrates that the male participants' (69\%) use of loan words in UMH were better than that of female participants $(51 \%)$. The highest percentage of correct answers provided by the male participants on the questionnaire was $97.5 \%$, whilst the highest percentage of correct answers provided by the female participants was $87.5 \%$. Additionally, Table 8 shows that $63 \%$ of the female participants used the loan word [tandah] 'The roof window of the car' more than the male participants (28\%). Based on my experience, many Meccan males consider this word girlish. Therefore, they do not use it as much as females do. Additionally, $45 \%$ of the female participants used the word [baxfi:f] 'tip' more than the male participants (30\%). On the basis of my knowledge of the Meccan society, this could be due to the fact that men prefer to use another word from UMH that shows their generosity, i.e., Rikraamiyyeh 'generous tip'. Similarly, $78 \%$ and $80 \%$ of the female participants used the words [s'ifir] 'zero' and [Yafa:rim] 'excellent' more than men did (58\% and $48 \%$ respectively) because men prefer to use other words in these contexts.

The reason for such results could be because many men in Mecca speak Turkish or Persian fluently. The acquisition of these languages has occurred without formal learning at schools or other educational institutions. In other words, they have acquired these languages. This acquisition may have taken place as a result of communicating with pilgrims. The acquisition of these words may have raised the awareness of men to the existence of loan words in UMH. Many families in Mecca used to be responsible for hosting and serving pilgrims of certain nationalities for years. Thus, the language spoken by the guests (Note 4) continued to be a 
common language among the hosting family for generations. Therefore, it can be suggested that men, especially elderly ones, had a high degree of contact with the pilgrim guests. Hence, they still speak the language, and in turn, they may know and use loan words from this language. In this regard, it is important to point out that Turkish and Iranian pilgrims were considered the richest and most prestigious in comparison to others nationalities. This means that they were able to afford their stay in Mecca. The fact that the pilgrims guests belonged to a prestigious class of the community may have encouraged their hosts to learn their language and continue speaking it.

On the other hand, women, especially elderly ones, tend to use fewer loan words compared to men. This could be due to the lack of contact with pilgrims. They used to serve the pilgrims staying at their houses through their husbands, fathers, sons, or other male relatives in their family. This may have led to their being less influenced by foreign languages.

With regard to younger women, I observed that they tend to belong to dense networks. Many younger women are housewives; thus, they spend a lot of time communicating with each other. For them, conforming to the speech norms of the prestigious group is of high importance. These norms are those that are similar to the dialect spoken in Jeddah, a city in Saudi Arabia. This dialect is associated with modernity and prestige. Similarly, Trudgill (1972, pp. 182-183) indicated that women have a greater tendency to follow community prestige norms as opposed to the linguistic behaviour of men. This situation is similar to the one found in Milroy's (1987) study. That is, all of the young Clonard women worked together. Working together meant that they are members of a dense network; hence, their lives were very much interconnected. The difference is that Meccan women do not leave Mecca to work in another place. In contrast, they stay at home, which means that their speech is less likely to be affected by foreign languages. In fact, it is much more likely to be affected by a regional dialect, i.e., Jeddah, rather than a foreign language. Even though Meccan women do not leave home, they go shopping to Jeddah every once and while, since the shopping centers there are up-to-date with the recent fashion. This means that they communicate with young women in Jeddah, at least in shopping centers. In a similar study by Trudgill (1972, pp. 182-183), he proposed that women's overt prestige orientation may result from their powerless position in the society. Specifically, Trudgill (1972, pp. 182-183) suggested that many societies may not allow women to increase their power and status via working in the market place. Thus, they resort to other sources, such as language, to improve their social status. In particular, as a response to their powerless position in the society, it appears to be that women opt for enhancing their linguistic strategies by imitating those who belong to high classes. This means that the factor that controls the change in women's speech is the socioeconomic hierarchy (Trudgill, 1972, pp. 182-183).

On the other hand, men's life is mostly outside of the house domain. They are the ones dealing with pilgrims, meaning that their speech is more likely to be affected by foreign languages than that of women. In fact, many young and middle aged men in Mecca work at the mosques, hotels, restaurants, the market, etc. These places are usually visited by pilgrims. Their use of the loan words could be accounted for by examining the environment in which they work. Dealing with pilgrims who speak various languages may encourage them to learn these languages. This knowledge may help them get better jobs and earn more money, especially in the religious tourism industry. Hence, they are more susceptible to being exposed to various languages and learning them in comparison with Meccan women.

\subsubsection{Educational Level}

Finally, I move on to discuss the third social factor, namely, educational level. Table 9 presents the results of the t-test of the participants in terms of educational level.

Table 9. Results of the t-test of the participants in terms of educational level

\begin{tabular}{lllllll}
\hline Educational level & Number of participants & Mean & Standard deviation & T score & Degree of freedom & P value \\
\hline Educated & 50 & 4.2 & 9.7 & 1.76 & 78 & 0.041 \\
Uneducated & 30 & 7.6 & 4.1 & & & \\
\hline$* * \mathrm{P}<0.05$ & & & & &
\end{tabular}

Table 9 demonstrates that the uneducated participants $(\mathrm{m}=7.6)$ used loan words in UMH than the educated participants $(\mathrm{m}=4.2)$. The fact that the $p$ value $(0.041)$ is less than $(0.05)$ demonstrates that the difference between the uneducated and educated participants was statistically significant. The education factor plays a role in the participants' use of loan words in UMH. The results of the three t-tests administered in the current study 
confirm the proposed hypotheses; they show that the use of loan words in UMH is influenced by social factors such as age, sex and educational level. The following table presents the results of each group in detail.

Table 10. The proportion of positive responses in each group in terms of education

\begin{tabular}{|c|c|c|c|}
\hline No. & Loan word & Educated & Uneducated \\
\hline 1. & [balkin] & $24 \%$ & $97 \%$ \\
\hline 2. & [bamba] & $16 \%$ & $77 \%$ \\
\hline 3. & [Yafa:rim] & $30 \%$ & $90 \%$ \\
\hline 4. & [sutya:nih] & $64 \%$ & $70 \%$ \\
\hline 5. & [baxfa] & $56 \%$ & $63 \%$ \\
\hline 6. & [boya] & $34 \%$ & $83 \%$ \\
\hline 7. & [kabbu:t] & $36 \%$ & $87 \%$ \\
\hline 8. & [kobri:] & $42 \%$ & $87 \%$ \\
\hline 9. & [bant'alo:n] & $38 \%$ & $60 \%$ \\
\hline 10. & [baxfi: $]]$ & $23 \%$ & $80 \%$ \\
\hline 11. & [tarzi] & $32 \%$ & $97 \%$ \\
\hline 12. & {$\left[\mathrm{ma}: \mathrm{s}^{\mathrm{s}} \mathrm{a}\right]$} & $64 \%$ & $83 \%$ \\
\hline 13. & {$\left[\mathrm{~s}^{\mathrm{s}} \mathrm{ifir}\right]$} & $82 \%$ & $90 \%$ \\
\hline 14. & [dzazmih] & $34 \%$ & $57 \%$ \\
\hline 15. & [ta:za] & $32 \%$ & $60 \%$ \\
\hline 16. & [?istisyo:n] & $52 \%$ & $73 \%$ \\
\hline 17. & [ko:re:k] & $54 \%$ & $80 \%$ \\
\hline 18. & [ki:s] & $86 \%$ & $73 \%$ \\
\hline 19. & [ Jant $\left.^{\varsigma} a\right]$ & $62 \%$ & $63 \%$ \\
\hline 20. & [zuqa:q] & $26 \%$ & $47 \%$ \\
\hline 21. & [bat'a:niyyeh] & $22 \%$ & $80 \%$ \\
\hline 22. & [tandah] & $60 \%$ & $87 \%$ \\
\hline 23. & [doyri:] & $80 \%$ & $53 \%$ \\
\hline 24. & [tilik] & $50 \%$ & $90 \%$ \\
\hline 25. & [bo:f] & $28 \%$ & $77 \%$ \\
\hline 26. & [ & $34 \%$ & $53 \%$ \\
\hline 27. & [turdzma:n] & $36 \%$ & $93 \%$ \\
\hline 28. & [dirkisyo:n] & $24 \%$ & $77 \%$ \\
\hline 29. & {$\left[\mathrm{t}^{\mathrm{s}} \mathrm{o} \mathrm{t}\right]$} & $30 \%$ & $90 \%$ \\
\hline 30. & [vi:1la] & $22 \%$ & $70 \%$ \\
\hline \multicolumn{2}{|c|}{ Total mean } & $42 \%$ & $76 \%$ \\
\hline
\end{tabular}

An examination of Table 10 shows that the uneducated participants' (76\%) use of loan words in UMH was higher than that of the educated participants $(42 \%)$. The highest percentage of correct answers provided by the uneducated participants was $97 \%$, whereas that of the educated participants was $86 \%$. Table 10 also shows that on certain items, the educated participants used some loan words more than the uneducated participants. For instance, $80 \%$ and $86 \%$ of the educated participants used the words [doyri:] 'straight' and [ki:s] 'bag', whereas $53 \%$ and $73 \%$ of the uneducated participants used them respectively. This difference could be due to the fact that these words are used frequently in the Meccan society based on my experience. The sentences in which these words were used in the questionnaire are the ones in which these words are mostly found. This may explain why the educated participants used them. The uneducated participants, on the other hand, used other words from $\mathrm{UMH}$ that are not familiar to me. After some investigation, I found that these words are used in certain communities in Mecca and that is why I did not know them.

One may suggest that the uneducated participants were the ones who knew and used loan words in UMH because they want to identify themselves as true UMH speakers. According to the uneducated participants, being identified as true Meccans means that they will be honoured with serving pilgrims who come to visit the holy city every year.

In contrast, the educated participants' results showed that their use of loan words in UMH is less than that of the uneducated participants. Since the educated participants, especially the young participants, have university degrees, they may want to show that to others by using the alternative of these words in Modern Standard Arabic (MSA). The ability to use MSA correctly is regarded as prestigious, since it is the only official variety of Arabic, besides, it is the language of the holy Quran. For instance, many of the educated participants use the word 
[hadi:gah] 'garden' and [wardi] 'pink' instead of the loan words [baxsha] and [bambi], respectively. They may consider the use of loan words in UMH as non-prestigious, since they recognise such use as local. This attitude could be because the educated participants believe that the use of loan words is associated with the variety spoken in the streets. Hence, for them, knowing or using these words is not preferred because it would make them be associated with lower classes. In addition, many of the educated participants answered the questionnaire by providing some English words instead of words in UMH. For example, some of the participants wrote the English word bridge instead of the Arabic word dzisir or the Turkish loan word kobri:. This may have occurred because these participants wanted to demonstrate that they can speak English, which is associated with prestige. Being able to speak English, in Mecca, means that the individual who speaks it can attain a good job with a good salary.

These results, specifically those related to education, are similar to those found by Koka (2014). In particular, it has been noted that the speech of the literate and illiterate groups exhibit remarkable variations in terms of the lexical items they use (Koka, 2014, p. 1081). The speech of the literate group is characterised by scientific, modern and technical terminologies as opposed to that of the illiterate group. Specifically, the literate group seems to demonstrate a tendency to remain up to date with the latest advances pertinent to modern inventions. This explains why they use lexical items from other languages such as English. They believe that borrowing words from various languages, especially English, may give them the ability to enrich their repertoire by including modern lexical items. In the current study, the educated participants also used English, so that they can be perceived as prestigious and modern as opposed to the uneducated participants who preferred to use the local dialect.

To sum up, the t-tests show that my hypothesis was confirmed, since there were statistically significant differences between the answers of the older vs. younger, male vs. female and educated vs. uneducated participants. The following section concludes the study and provides some recommendations for further research.

\section{Conclusion and Recommendations}

The results revealed that most loan words ( 30 words) used by UMH speakers can be traced back to Turkish. The influence of Turkish has been attributed to the fact that Saudi Arabia was under the control of Ottomans for approximately 400 years. These words could have found their way into UMH as a result of pilgrimage. With respect to the second research question, the results showed that the older participants (74\%) used the loan words more than the young speakers $(60 \%)$. The main reason for the older speakers' use of loan words could be because old people living in Mecca have lived in the period during which Ottomans ruled the Arabian Peninsula. In contrast, it has been proposed that the younger speakers of UMH do not know the origin of these words because they believe that they are originally part of their language. Additionally, young speakers of UMH are possibly under more pressure from their peers to speak English rather than UMH.

Regarding sex, the results showed that male participants $(69 \%)$ used loan words more than the female participants (51\%). I argued that the reason for this result could be because many men in Mecca speak Turkish or Persian fluently. Therefore, they are more likely to know and use the loan words in UMH. Additionally, many men have more opportunities to deal with pilgrims than women do. Conversely, it has been suggested that women's use of the loan words in their dialect could be less than that of men because they are more eager to speak like young women in Jeddah, since it is more prestigious.

With regard to the educational level, the results demonstrated that the difference between the uneducated (76\%) and educated (42\%) participants was statistically significance. It has been concluded that the results of the three t-tests administered in this study confirm my hypothesis; they show that the use of loan words in UMH are influenced by social factors such as age, sex and educational level. I argued that the uneducated participants, especially those who were old, were the ones who knew and used loan words in UMH because they want to identify themselves as true UMH speakers. Conversely, the educated participants' results showed that their use of loan words in UMH is less than that of the uneducated participants. I argued that since the educated participants, especially the young participants, have university degrees, they may want to show that to others by using the alternative of these words in Modern Standard Arabic (MSA).

Finally, it is recommended that the loan words in other dialects in Saudi Arabia need to be investigated and compared with the results of this study in order to check whether they are similar or different. Additionally, it is suggested that the influence of the dialect of Jeddah on the speech of young Meccan women needs to be investigated. The degree of this influence could help in understanding the reasons why young women want to imitate this dialect. This analysis may offer a better understanding of the Saudi society and its socioeconomic 
hierarchy.

\section{References}

Ahangari, F., \& Moradi, N. (2013). Borrowing of Persian words into Arabic language and its influence on Arabic literature and language: A review paper. International Journal of Language Studies, 7(2), 143-153.

Aldakeer, A. (2015). Twitter account. Retrieved from https://twitter.com/a_althukair. DARE questionnaire. Retrieved from http://dare.wisc.edu/

Alotaibi, A. M. (2015). The awareness of euphemism by Kuwaiti speakers of Arabic. International Journal of Linguistics, 7(1), 69-81. http://dx.doi.org/10.5296/ijl.v7i1.6428

Altakhaineh, A. R. M., \& Rahrouh, H. N. (2015). The Use of Euphemistic Expressions by Arab EFL Learners: Evidence from Al Ain University of Science and Technology. International Journal of English Linguistics, 5(1), 14-21. http://dx.doi.org/10.5539/ijel.v5n1p14

Carver, G. M. (1987). American Regional Dialects. Michigan: University of Michigan Press.

Chambers, J. K. (1994). An introduction to dialect topography. English World-Wide, 15, 35-53.

Chambers, J. K., \& Heisler, T. (1999). Dialect topography of Quebec city English. Canadian Journal of Linguistics, 44, 23-48. http://dx.doi.org/10.1075/eww.15.1.03cha

Cheshire, J., \& Milroy, J. (1993). Syntactic variation in non-standard dialects: Background issues. In J. Milroy \& L. Milroy (Eds.), The Grammar of English Dialects in the British Isles (pp. 3-33). Harlow: Real English.

Grondelaers, S., \& Geeraerts, D. (2003). Towards a pragmatic model of cognitive onomasiology. In H. Cuyckens, R. Dirven, \& J. Taeldeman (Eds.), Cognitive Approaches to Lexical Semantics (pp. 67-92). Berlin/New York: Mouton de Gruyter.

Hurgronje, S. (1886). Mekkansiche Sprichwörter und Redensarten gesammelt und erläutert ... Haag: Nijhoff. Royal Netherlands Institute of Southeast Asian and Caribbean Studies (pp. 433-576).

Ibn Khaldūn, I., \& Rosenthal, F. (1967). The Muqaddimah. Princeton, NJ: Princeton Univ. Press.

Ingham, B. (1971). Some characteristics of Meccan speech. Bulletin of the School of Oriental and African Studies, 34(2), 273. http://dx.doi.org/10.1017/S0041977X00129544

Johnson, E. (1996). Lexical Change and Variation in the Southeastern United States 1930-1990. Tuscaloosa: University of Alabama Press.

Koka, N. A. (2014). A sociolinguistic investigation of social stratification and linguistic variation among the Kashmiri speech community. Journal of Language Teaching and Research, 5(5), 1071-1084. http://dx.doi.org/10.4304/jltr.5.5.1071-1084

Labov, W. (1972). Sociolinguistic Patterns. Philadelphia: University of Pennsylvania Press.

McMahon, M. S. (1994). Understanding Language Change. Cambridge: Cambridge University Press. http://dx.doi.org/10.1017/CBO9781139166591

Meyerhoff, M., Schleef, E., \& Mackenzie, L. (2015). Doing Sociolinguistics: A practical guide to data collection and analysis. London: Routledge.

Milroy, L. (1987). Language and Social Networks. New York: Blackwell.

Nakshabandi, A. (1992). A linguistic investigation of the dual and plural forms of some borrowed words in the Jeddah dialect of Arabic. Art, 5(1), 3-13. http://dx.doi.org/10.4197/art.5-1.1

Romanisation of Arabic. (2015). Wikipedia. Retrieved from https://en.wikipedia.org/wiki/Romanization_of_Arabic

Suleiman, Y. (1994). Arabic Sociolinguistics. Richmond, Surrey: Curzon Press.

Suleiman, Y. (2003). The Arabic Language and National Identity. Washington, D.C.: Georgetown University Press.

Tagliamonte, S. (2006). Analysing Sociolinguistic Variation. Cambridge: Cambridge University Press. http://dx.doi.org/10.1017/CBO9780511801624

Trudgill, P. (1972). The Social Differentiation of English in Norwich. Cambridge: Cambridge University Press. 


\section{Notes}

Note 1. Information about DARE was retrieved on 11th July 2015 from http://dare.wisc.edu/.

Note 2. Since UMH has no written form, Arab speakers tend to use MSA in writing.

Note 3. The Romanisation system used in this study is based on the one used in Wikipedia https://en.wikipedia.org/wiki/Romanization_of_Arabic.

Note 4 . The guests were mostly men. Due to the conservative nature of the society, men avoid bringing their wives, daughters, sisters, etc. to stay at another family's house.

\section{Appendix A. The Questionnaire}

\section{Questionnaire in English}

- Ethical Consent Form

\section{Dear participants,}

My name is Sameeha Al-Ahmadi and I am an MA student at Newcastle University/ Newcastle upon Tyne, UK. You are invited to join a research study to look at lexical variation in Meccan Hijazi Arabic. Participation in this study is voluntary. You have the right not to participate at all or to leave the study at any time. Deciding not to participate or choosing to leave the study will not result in any penalty. If you decide to participate, you will be asked to provide answers to the questionnaire below, which will take you 15 minutes to complete. You are not asked to provide your names or any personal information about you, and I will take the necessary steps to keep any information about you confidential, and to protect it from unauthorized disclosure, tampering, or damage. I cannot guarantee that you will personally experience benefits from participating in this study, but your participation will help us understand the changes that are taking place in Meccan Hijazi Arabic, so I do appreciate the effort you are willing to exert if you decided to participate. If you have any questions about the study or if you would like to have a copy of the final results of this study, please do not hesitate to contact me or my supervisor Dr. Adam Mearns via the following emails: s.d.a.al-ahmadi@ncl.ac.uk

Sincerely,

Sameeha Al-Ahmadi

Tel: 00966555831119

Signature of the research participant: 


\section{Part 1: Background information}

1. Age:
a) $20-35$
b) $36-45$
c) $46-70$
d) $70+$

2. Sex:

a) male

b) female

3. Place of birth:

4. Education:
a) None
b) Primary school
c) Secondary school
d) University degree
e) Higher education

\section{Occupation:}
a) Student
b) Labourer
c) Housewife
d) Government employee
e) Other:
6. Place of work/study:
a) Home
b) Mecca city
c) Another city in Saudi Arabia
d) Outside the country

7. Have you ever lived outside Mecca city area?

a) Yes

8. If yes, how long?

9. Why did you go there?
a) Travel
b) Study
c) Work
d) Trade
e) Other reasons:

10. Have you ever lived for more than a month outside Mecca city area?
a) Yes
b) No

11. Do you want to work/study in places outside Mecca city?

a) Yes 
b) No

\section{Part 2: Use of loan words in UMH:}

12. When your friend invites you suddenly to dine with her without prior planning and you are not sure whether you want to go or not, you may answer her:

13. What do you call the colour in the picture

14. When your son/daughter solves a difficult puzzle which you find very difficult, you may complement him/her by saying:

15. What do you call this

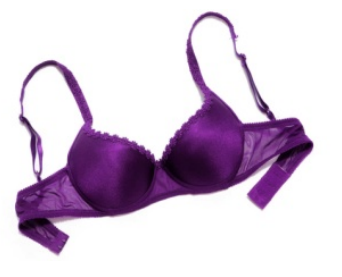

16. What do you call the small garden usually found by the street sides, in which people used to sit for a short-time picnic?

17. After they bought the new house, they wanted to buy to paint the walls.

18. Which part of the car do you usually open when you go to a car mechanic

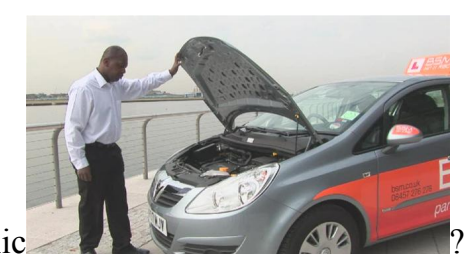

19. What do you call the structure on which vehicles move

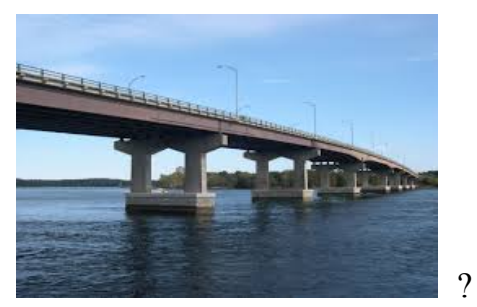

20. What do you call this

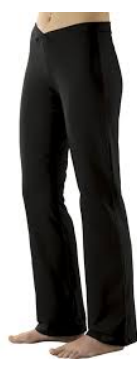

21. When you go to a restaurant and the waiter/waitress servers you in a good manner, what do you usually 
give him/her to show that you liked the way he/she served you?

22. I usually go to the to fix my clothes.

23. What do you call this

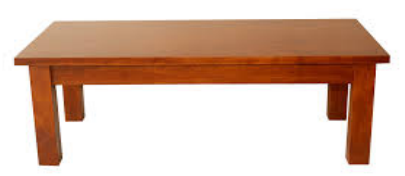

24. What is the result of this mathematical equation: $1-1=$ ?

25. When winter came, Ahmad went to the shop and bought this

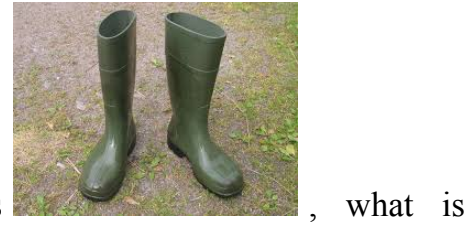
it?

26. I only buy meat, I can never eat frozen meat.

27. While we were travelling to Jeddah, we stopped by the to fill the tank because we were out of gas.

28. My father asked my mother to bring a because he wanted to plant tomato in the garden.

29. Ali asked for another
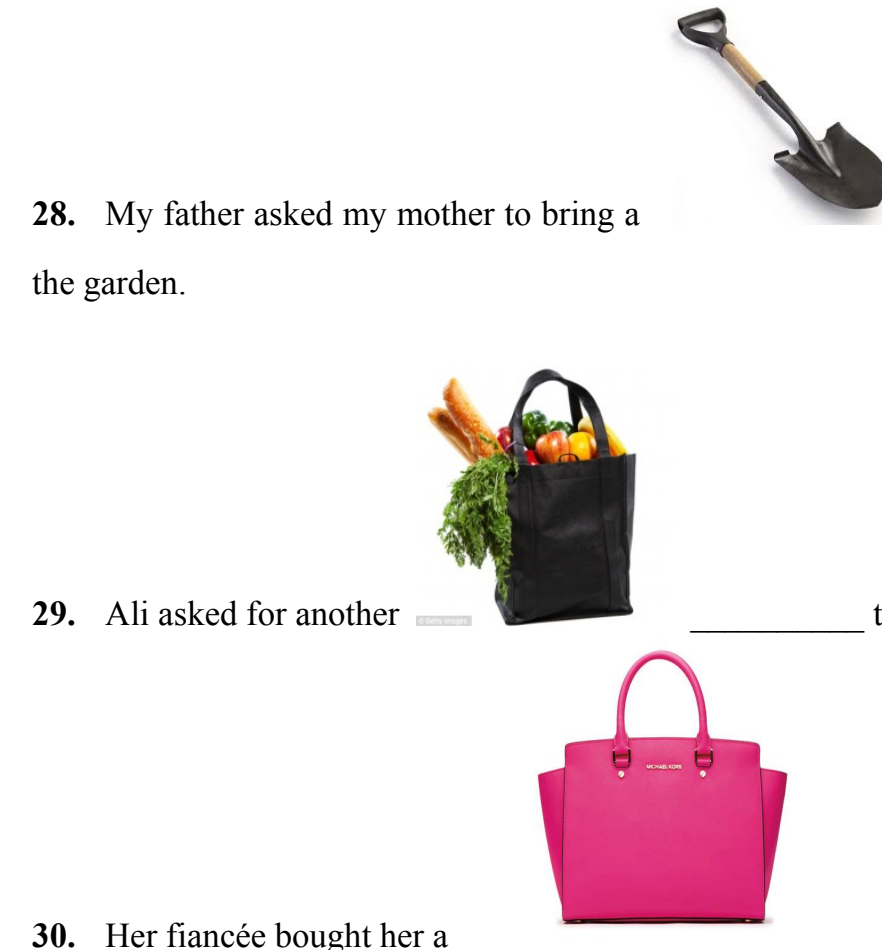
cocause he wanted to plant tomato in the garden.

30. Her fiancée bought her a to put the bread in when he went to the supermarket. 
31. What do you call the narrow street

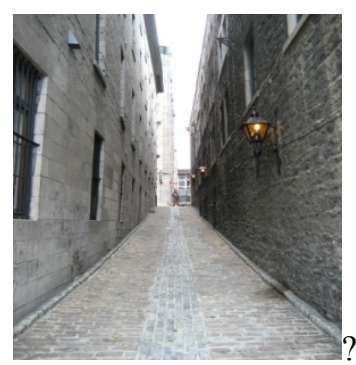

32. Because her husband was feeling cold, Layla covered him with a so he won't catch a cold.

33. What time is it?

34. When Kamal graduated from the university, he went out with his friends and got out of the car's

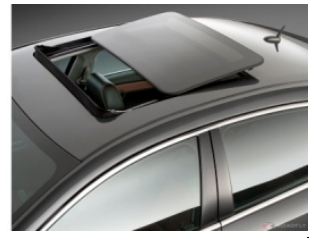
to sing loudly.

35. Mohammad told the driver: stay with me, don't beat around the bush!

36. When you are inside the house, do you put on

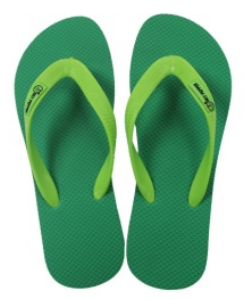

37. What does bo: $\int$ mean in this sentence: he went to the supermarket to buy juice and he came back bo: $\int ?$

38. What do you call this

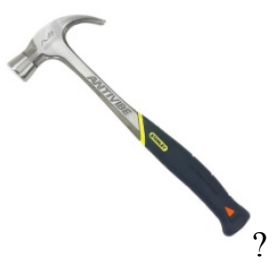


39. I don't understand Spanish; I need a to translate the words to me.

40. What do you call this

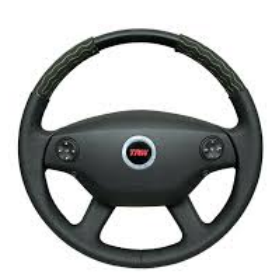

$?$

41. When you mop the floor, do you put the water in a

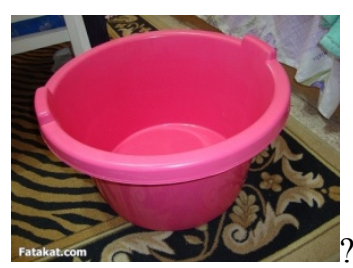

42. Not everyone can afford to live in a

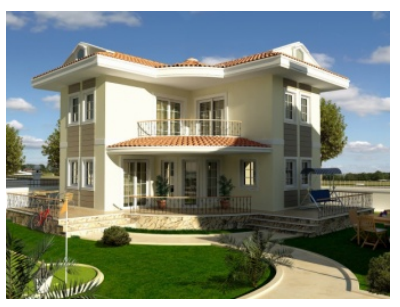
, only rich people can!

43. What is the capital of Sudan? 


\section{Arabic version}

\section{الاستبيان باللغة العربية}

$$
\begin{aligned}
& \text { • نموذج الموافقة على المشاركة في الدراسة } \\
& \text { السادة/السيدات الأفاضل، }
\end{aligned}
$$

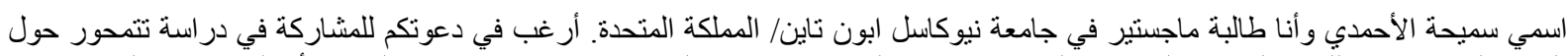

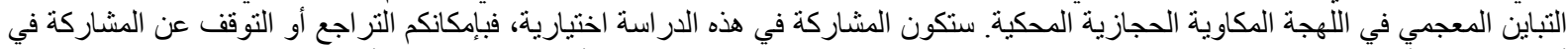

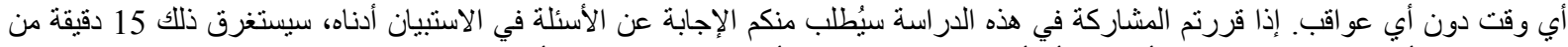

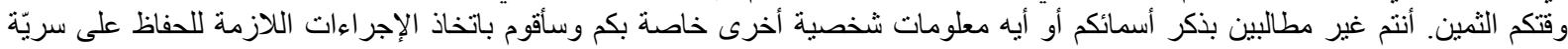

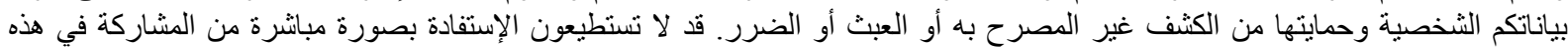

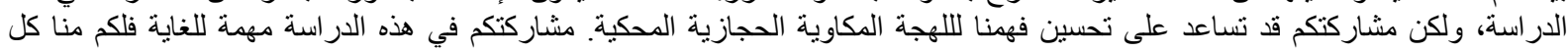
الاحتر ام و التقدير. إذا كانت لديكم أية أسئلة حول هذه الدراسة أو إذا كنتم ترغبون في الحئن الحصول على ملخص للنتائج، فلا تترددوا في التواصل معي عبر البريد الالكتروني الخاص:

.s.d.a.al-ahmadi@ncl.ac.uk وتفضلو ا بقبول فائق الاحتر ام، سميحة الأحمدي هاتف:00966555831119 توقيع المشارك/المشاركة في الدراسة: 
الجزء الأول: المعلومات الأساسية

1

35-20 (أ)

45-36 (ب

70-46 (د)

$+70$

2

3

4.

أ) لأل يوجد

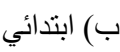

ج) ثانوي

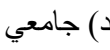

ه) در اسات عليا

5.

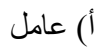

ب) طالب

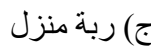

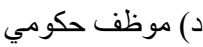
0) أخرى: موط

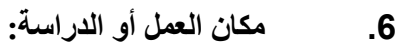

أ) المنزل

ب) مدينة مكة

ج) مدينة أخرى في السعودية

د) خارج الدولة مدينه اخرى

هل سبق وأن عشت خارج مدينة مكة:

.7

أ) نعم

ل

إذا كانت إجابتك نعم في السؤال السابق، كم المدة؟

.8

لماذا ذهبت للعيش خارج مكة؟

.9

أ) سفر

ب) در اسة بلة 


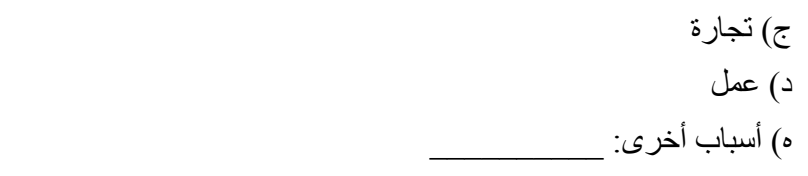

هل سبق وأن عشت أكثر من شهر واحد خارج مدينة مكة؟

.10

أ) نعم

ل ب (ب)

هل ترغب بالعمل/الاراسة في أماكن خارج مدينة مكة؟ .11

أ) نعم

ل

الجزء الثاني: معرفتك بالكلمات المستعارة في لهجتك المحكية

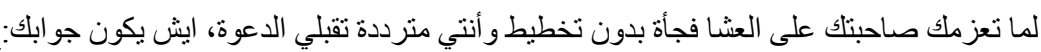
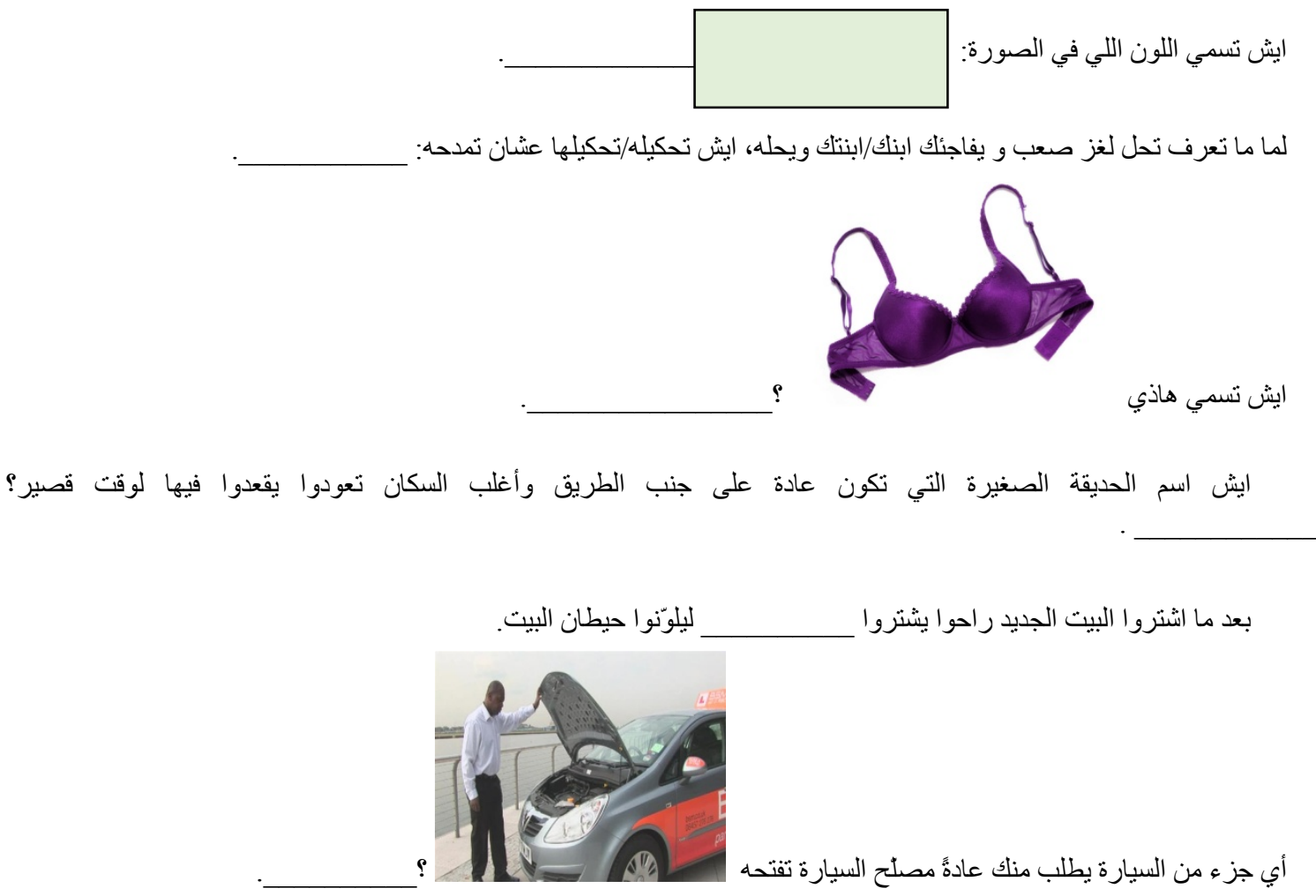

ايش اسم الحديقة الصغيرة التي تكون عادة على جنب الطريق وأغلب السكان تعودوا يقدوا فيها لوقت قصبر؟

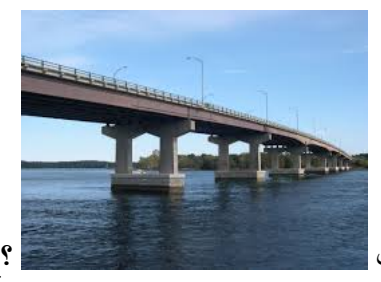




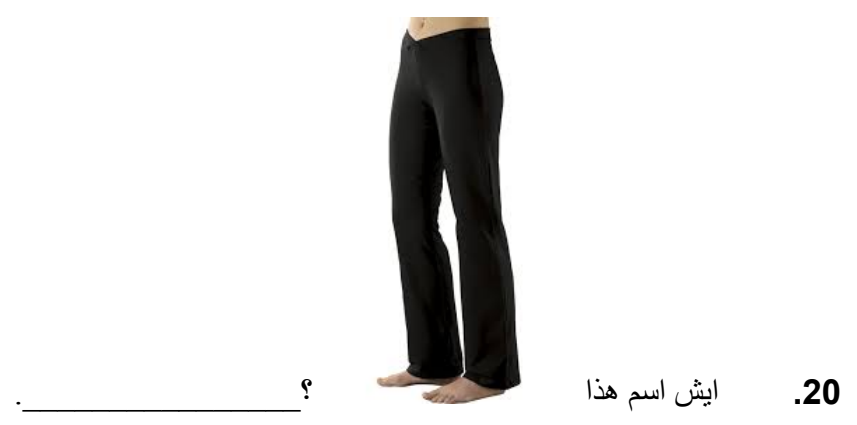

21. الزينة؛

عشان أصلح أو اعيي وبدلاتي. أروح في العادة على

.22

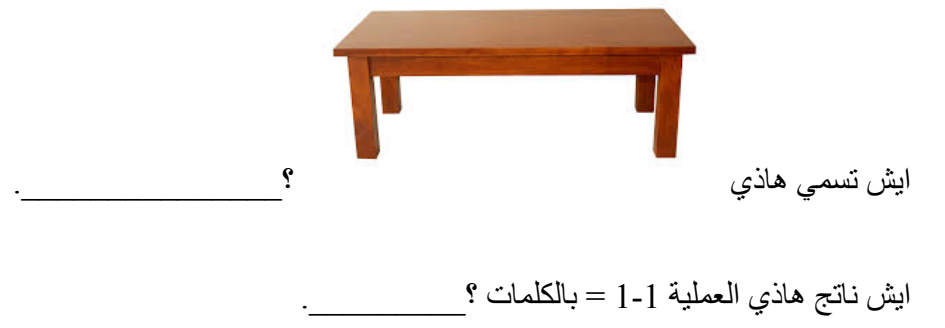

.23

.24

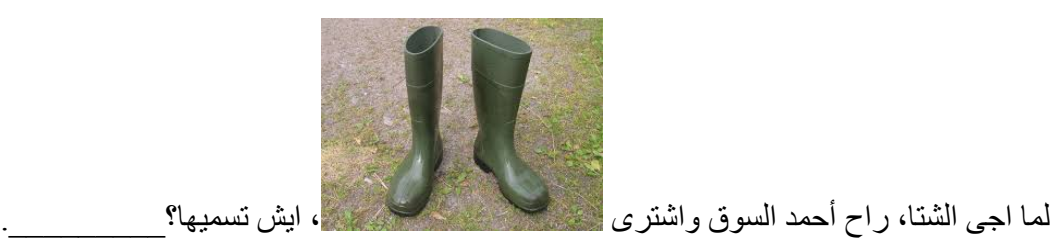

بس، لأنو ما أحب اللحمة المجمدة أبداً. أنا آكل اللحمة

.26

عشان نعبي بنزين لأنو التنك خلص. و احنا مسافرين على جدة، وقفنا عند

.27

عثان بزر ع بندورة في الحديقة.

ابوي طلب من امي

.28

عشان يحط فيه الخبز.

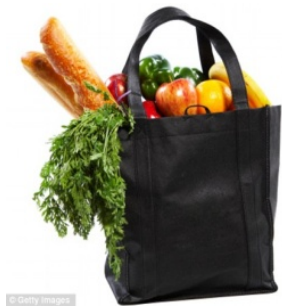

لماراح علي على السوبرماركت، طلب كمان 


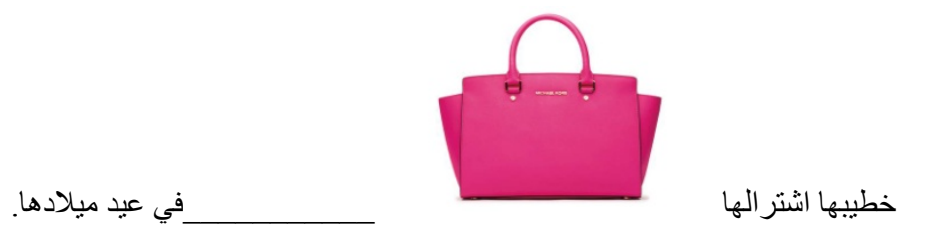

.30

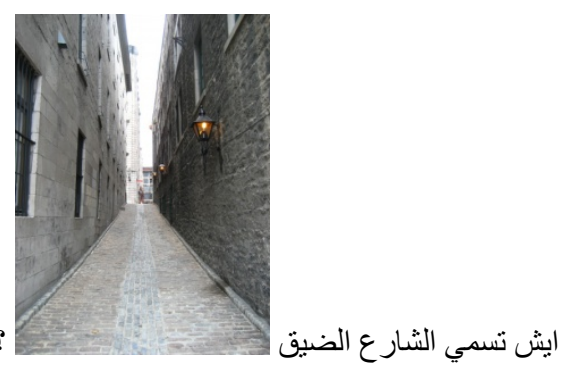

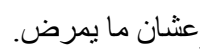

ليلى شافت زوجها بردان فحطت عليه

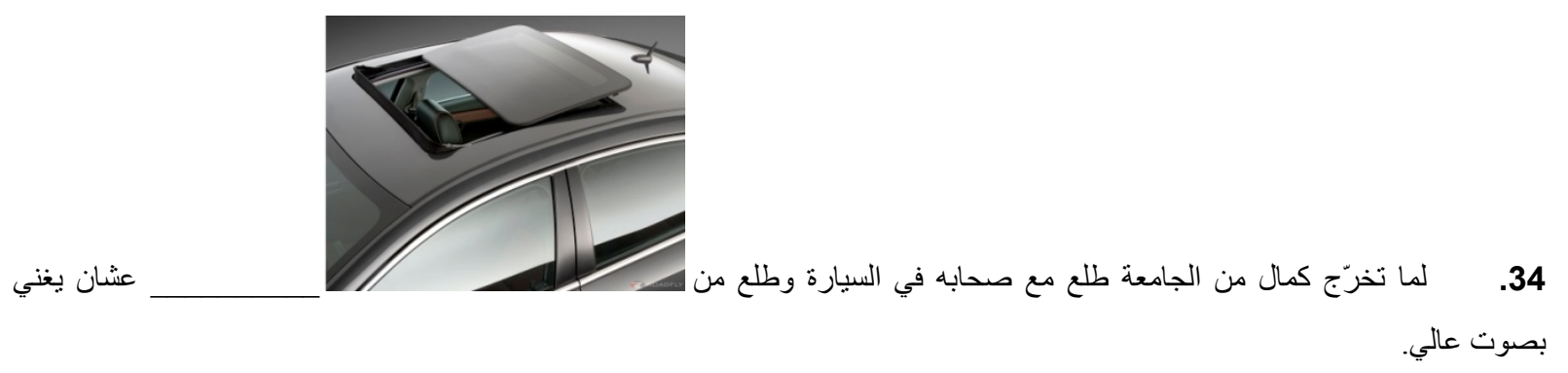

معي، أنا ما بحب اللف و الدوران! حكى محمد للدريويل خليك

برجلك ؟ 

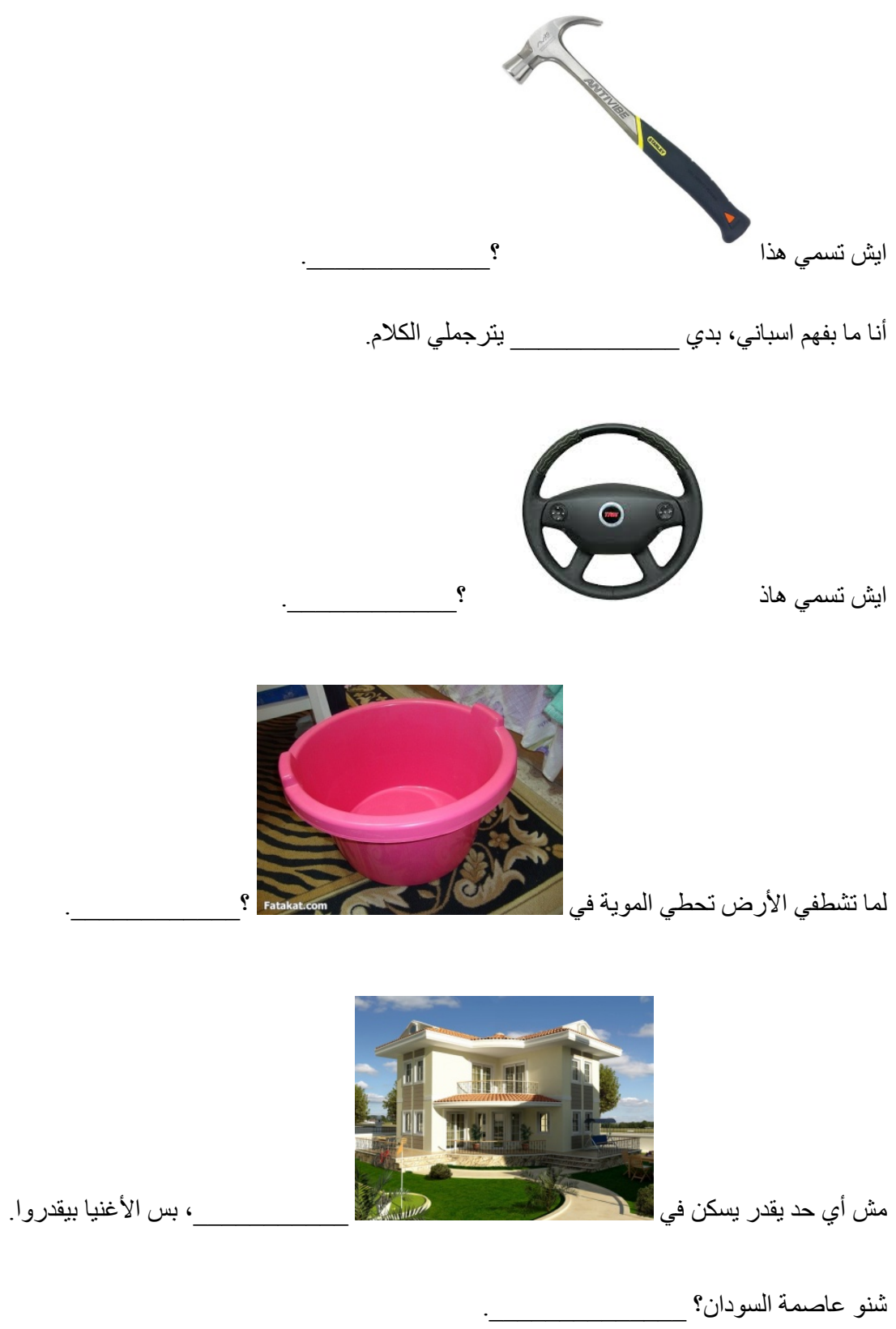

\section{Copyrights}

Copyright for this article is retained by the author(s), with first publication rights granted to the journal. This is an open-access article distributed under the terms and conditions of the Creative Commons Attribution license (http://creativecommons.org/licenses/by/3.0/). 